\title{
Improving Design Performance of Students in Interior Architecture Undergraduate Education
}

\author{
Deniz Ayşe Yazıcıŏglu* \\ Istanbul Technical University, Faculty of Architecture, Interior Architecture Department, Taşkışla, Taksim, Istanbul/Turkey \\ *Corresponding author: denizayseyazicioglu@gmail.com, yazicioglude@itu.edu.tr
}

Received March 08, 2015; Revised March 29, 2015; Accepted April 23, 2015

\begin{abstract}
Considering the developing conditions in interior architecture undergraduate education and inevitability of performing restructuring works to this end is a reality expressed also in the literature. "Performance-based design" is one of the key concepts in this approach. When the works as to interior design project performance are examined it can be observed that conducting assessments of user recognition correctly and fully at the preliminary stage of project is an important component affecting the design performance. This is because the success of interior space design is measured by considering to what extent the requirements of the users are met. In this context, the purpose of this study has been designated as the creation of documents the students will benefit from while determining user requirements at the preliminary stage of the project within the purview of "Interior Architecture Design Studio" courses within the interior design undergraduate education. The scope of the study is limited to only residential interior design projects with an eye to reach a more elaborate result. Literature and practical application resources were researched to determine the documents utilized for recognizing the users in residential interior design as methodology at the first stage in line with the scope and purpose defined. Subsequently, all the documents obtained were examined by making comparisons in a systematic manner and the shortcomings of the cited documents were revealed. And in the final stage, suggestions were made with a view to overcome these shortcomings. It will be possible to determine user requirements more accurately through utilization of documents created in line with suggestions to be made within the purview of the study at the preliminary stage of residential interior design projects by interior architecture undergraduate students and this will increase the students' success as to designing significantly.
\end{abstract}

Keywords: performance based design, interior architecture education, user requirements, client questionnaire, home interior architecture

Cite This Article: Deniz Ayşe Yazıcıoğlu, "Improving Design Performance of Students in Interior Architecture Undergraduate Education.” American Journal of Educational Research, vol. 3, no. 5 (2015): 604609. doi: 10.12691/education-3-5-12.

\section{Introduction}

Considering the developing conditions in interior architecture undergraduate education and inevitability of performing restructuring works to this end is a reality expressed also in the literature. "performance-based design" is one of the key concepts in this approach and it is inevitable to reconsider the entire design process with an integrated point of view to this end $[1,2,3]$.

When the studies as to interior design project performance are examined it can be observed that conducting assessments of user recognition correctly and fully at the preliminary stage of project is an important component affecting the design performance. This is mainly because the success of interior space design is measured by considering to what extent the requirements of the users are met. Addi and Lytle assert that priority of users in design of interior spaces is "designing functional spaces which serve their needs". Hence, they emphasize the need for establishing collaboration with the user in the design process with an eye to understand the user [4]. Ching [5] underlines the importance of taking into account the users and their action requirements to understand the functionality of interior space in the best and most accurate way and to meet the requirements related thereto. Arcan and Evci [6] express that the user is the criteria for everything in the design process and that the combination of single-actions which takes place due to requirements of the user and which is the most important element to be considered during this process constitute the action area while the combination of action areas constitute the usage areas. In this context, they stress the fact that design of the interior space is realized by arrangement of the action areas and required equipments with appropriate circulation areas. In other words, the inner space is formed according to the user thereof. Stephenson and Stephenson [7] indicate in a way to support all these thoughts that the designer may have valuable ideas at the starting point however they are of no importance if any of these ideas are incoherent with the user's requirements [3].

Furthermore, usage of "client questionnaire" to understand the user requirements at the preliminary stage 
of interior design provides the following additional benefits which help the progression of the design process $[8,9]$ :

1. It translates the research objectives into specific questions that are asked of the respondents.

2. It standardizes those questions and the response categories so every participant responds to identical stimuli.

3. By its wording, question flow, and appearance, it fosters cooperation and keeps respondents motivated throughout the interview.

4. Questionnaires serve as permanent records of the research.

5. They speed up the process of data analysis.

6 . They contain the information upon which reliability assessments such as test-retest or equivalent-form questions may be made, and they are used in follow-up validation of respondents' participation in the survey.

The requirements of the user are determined in consultation therewith at the beginning of the design process due to all these reasons. Various "Client Questionnaires" are available to help the designer to make the right determinations at this stage. Personal meetings are very important to design process. First meeting with client usually runs one-and-a-half to two hours, during which time they discuss and take detailed notes on client's needs, wants, ideas and ideals [10]. If the data obtained by the "Client Questionnaire" is complete and accurate, it will significantly improve the designer's performance in the design process [3]. Because client questionnaire translates the research objectives into specific questions that are asked of the respondents. It standardizes those questions and the response categories so every participant responds to identical stimuli. By its wording, question flow, and appearance, it fosters cooperation and keeps respondents motivated throughout the interview. Questionnaires serve as permanent records of the research. They speed up the process of data analysis [8].

In this context, determination of user requirements correctly and acquiring skills for developing their projects is of utmost importance within the scope of the "Interior Architecture Design Studio" courses during the undergraduate education of interior architecture students. This is because the skill they gain will contribute to increase their design performance significantly in their professional life.

\section{Purpose and Methodology}

In this context, the purpose of this study has been designated as the creation of documents the students will benefit from while determining user requirements at the preliminary stage of the project within the purview of "Interior Architecture Design Studio" courses within the interior design undergraduate education. The scope of the study is limited to only residential interior design projects with an eye to reach a more elaborate result. Literature and practical application resources will be researched to determine the documents utilized for recognizing the users in residential interior design as methodology at the first stage in line with the scope and purpose defined. Subsequently, all the documents obtained will be examined by making comparisons in a systematic manner and the shortcomings of the cited documents will be revealed. And in the final stage, the kind of documents the interior architecture undergraduate students will benefit within the scope of "Interior Architecture Design Studio" courses will be described in order that they can determine user requirements fully and correctly by taking into account these shortcomings.

\section{Documents Used for Determination of User Requirements in Residential Interior Design}

Literature and practical application resources were researched to determine the documents utilized for user requirements in residential interior design at the first stage. A total of 172 questions in 19 different resources were reached basing on the results of these researches. [11-29]. Subsequently, the mentioned 172 questions were reduced to a total of 95 questions in a comparative manner as seen in Table 1, by eliminating the similar questions.

Table 1. Questions for determining user requirements in residential interior design

\begin{tabular}{|c|c|}
\hline No & Questions \\
\hline 01 & What is the scope of project? \\
\hline 02 & What is the size/volume of home? \\
\hline 03 & Number of rooms of home? \\
\hline 04 & What is the location of project? \\
\hline 05 & Which rooms will be included in the project? \\
\hline 06 & Is this your own place or rented? \\
\hline 07 & $\begin{array}{l}\text { How long have you lived in your home and how long do you plan } \\
\text { to live in your home? }\end{array}$ \\
\hline 08 & Do you enjoy specific rooms for specific functions? \\
\hline 09 & Do you have plans for the future use of your residence? \\
\hline 10 & Household members (name, work space,special needs, birthday) \\
\hline 11 & Do you anticipate changes for any household members? \\
\hline 12 & Will your rooms need to serve different functions in the future? \\
\hline 13 & Do you have pets in household? List type, age, special needs \\
\hline 14 & Special considerations (disabled, elderly or children)? \\
\hline 15 & What is your lifestyle? \\
\hline 16 & How is your home entrance and entrance door? \\
\hline 17 & What size of entrance closet do you envision? \\
\hline 18 & What is your entertaining style? \\
\hline 19 & What is the frequency of your entertaining? \\
\hline 20 & What is the average number of guests? \\
\hline 21 & What is the average guests ages (adults/teenagers/children)? \\
\hline 22 & How important is TV to you, in which rooms? \\
\hline 23 & Should the living room be open to other areas? Which rooms? \\
\hline 24 & What are the primary activities will take place in living room? \\
\hline 25 & Will living room need more than one seating area? \\
\hline 26 & What furnishings do you envision in living room? \\
\hline 27 & What cooking facilities are required? \\
\hline 28 & Does more than one person cook at a time? \\
\hline 29 & What is your eating habits? \\
\hline 30 & Where do you eat your meals? \\
\hline 31 & Do you like to look out the window while working in kitchen? \\
\hline 32 & How many feet of countertop do you need in your kitchen? \\
\hline 33 & How much cupboard/drawer space do you need in your kitchen? \\
\hline 34 & Is an island important in your kitchen? \\
\hline 35 & Would you use timbers to hang pots and pans in your kitchen? \\
\hline 36 & What non-food items do you store in your kitchen? \\
\hline
\end{tabular}


37

38

39

40

41

42 Describe your privacy requirements you have for the bedroom?

43 Is a separate dressing area required in bedroom?

44 Will the bedroom be also used as a study or sitting room?

45 What special qualities do you like in a bathroom?

46 How private should the bathroom be from the rest of the home?

47 Do you like to be able to see out of a window in bathroom?

48 How long of a countertop would you like in bathroom?

49 Do you need a separate makeup area in bathroom?

50 Should the toilet be in a separate space?

51 Do the household members share common time around home?

52 Do you have any collections? If yes, please list

53 Are you looking to create a children's play area?

54 Does any household member work from home?

55 What type of lighting requirements will be necessary in rooms?

56 Is there natural light in the room(s)?

57 Do you need special storage area?

58 How many fireplaces would you like? Where?

59 How do you spend your vacation time?

60 Do you have hobbies? If yes what kind of hobbies?

61 What is the budget for your project?

62 What kind of enhancements are you considering?

63 What do you like/dislike most about your current home? Why?

64 What is your favorite room in the home? Why?

65 Are there any pieces of furniture, window, wall or floor

65 coverings that must stay or go, and be worked into the new plan?

66 What is your personal design goals for your home?

67 Would you like to include "green products" when possible?

68 What mood do you want to create overall?

69 Would you like an open concept, semiopen or mostly closed?

70 What is the existing style of your home?

71 What style do you like and dislike?

72 What are your favorite/unfavorite color?

73 What are your favorite/unfavorite pattern?

74 What colors do you currently have in your home?

75 Do you have a color theme in mind?

76 Do you like false ceilings?

77 What kind of materials do you prefer?

78 Are there types of window treatment you prefer?

79 Are there types of door treatment you prefer?

80 Do you need sun control or privacy with window treatments?

81 What is the timeframe of the project?

82 What has prevented you from doing so?

83 What are some of the ideas you have considered so far?

84 Who will be making the financial decisions on the project?

85 Who are the decision makers?

86 What are the description of rooms (Size/Ceiling/Height)?

87 Do the household members share common time in the home?

88 What furniture store/catalog would you most likely buy from?

89 Why are you interested in doing this project at this time?

90 Who will be involved in this project? How?

91 What is most important to you-the budget or the result?

92 If you have a patio, terrace etc, what is your ideas for them?

93 Do you want to have an internal staircase?

94 Any extra space layout requirements that you might want?

95 Are you interested in purchasing at retail or customizing interior?

When the distribution of questions used to determine the user requirements as to residential interior design listed in Table 1 were examined by resources they were found to be as provided in Table 2.

Table 2. Distribution of questions used to determine the user requirements by resources

일

References

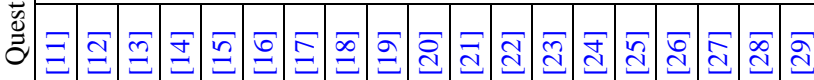

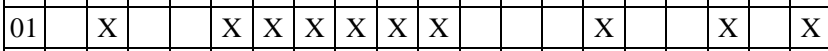

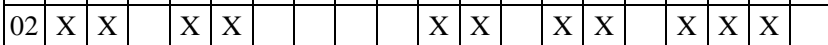

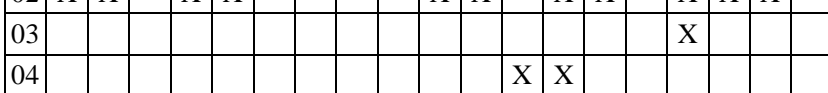

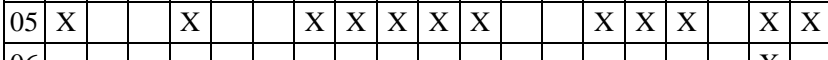

\begin{tabular}{|l|l|l|l|l|l|l|l|l|l|l|l|l|l|l|l|l|l|l|l|}
\hline 06 & & & & & & & & & & & & & & & & & & $\mathrm{X}$ & \\
\hline 07 & $\mathrm{X}$ & & & & & & & & & $\mathrm{X}$ & $\mathrm{X}$ & & & $\mathrm{X}$ & & $\mathrm{X}$ & & & \\
\hline
\end{tabular}

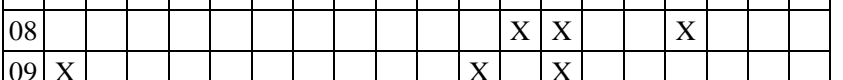

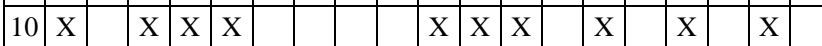

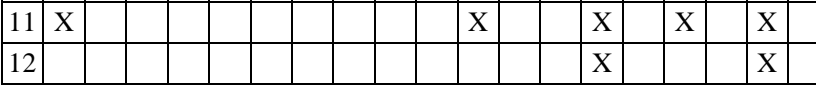

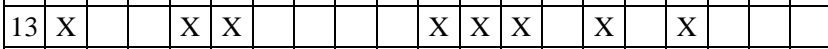

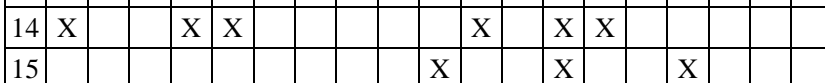

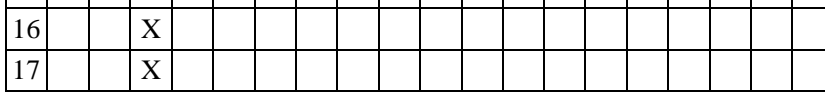

\begin{tabular}{|l|l|l|l|l|l|l|l|l|l|l|l|l|l|}
\hline 18 & $\mathrm{X}$ & & $\mathrm{X}$ & $\mathrm{X}$ & & & & & & $\mathrm{X}$ & $\mathrm{X}$ & $\mathrm{X}$ & $\mathrm{X}$ \\
\hline
\end{tabular}

\begin{tabular}{|l|l|l|l|l|l|}
\hline 19 & $\mathrm{X}$ & & $\mathrm{X}$ & $\mathrm{X}$ \\
\hline
\end{tabular}

\begin{tabular}{l|l|l|l|l|l}
\hline 20 & $\mathrm{X}$ & & $\mathrm{X}$ \\
\hline
\end{tabular}

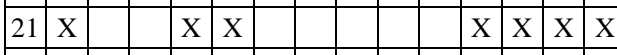

22

23

24

25

26

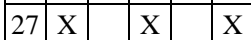

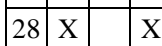

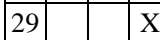

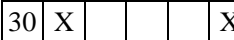

\begin{tabular}{|l|l|l|l|}
\hline 31 & & & $\mathrm{X}$ \\
\hline 32 & & & $\mathrm{X}$ \\
\hline
\end{tabular}

\begin{tabular}{|l|l|l|l|}
\hline 33 & & & $X$ \\
\hline 34 & & & $X$ \\
\hline
\end{tabular}

\begin{tabular}{l|l|l|l|}
\hline 35 & & & $X$ \\
\hline
\end{tabular}

\begin{tabular}{|l|l|l|l|}
\hline 36 & & & $\mathrm{X}$ \\
\hline 37 & & & $\mathrm{X}$
\end{tabular}

\begin{tabular}{ll|l|}
\hline 37 & & $\mathrm{X}$ \\
\hline
\end{tabular}

\begin{tabular}{|l|l|l|l|}
\hline 38 & & & $X$ \\
\hline 39 & & & $X$ \\
\hline
\end{tabular}

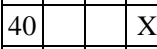

\begin{tabular}{ll|l|}
\hline 41 & & $\mathrm{X}$ \\
\hline
\end{tabular}

\begin{tabular}{|l|l|l|}
\hline 42 & & \\
\hline
\end{tabular}

\begin{tabular}{|l|l|l|}
\hline 43 & & $\mathrm{X}$ \\
\hline
\end{tabular}

44

45

46

47

\begin{tabular}{ll|l|l|}
\hline 48 & & $\mathrm{X}$ \\
\hline
\end{tabular}

\begin{tabular}{|l|l|l|}
\hline 49 & & \\
\hline
\end{tabular}

\begin{tabular}{|l|l|l|}
\hline 50 & & $\mathrm{X}$ \\
\hline
\end{tabular}

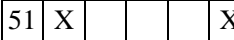

52 X

\begin{tabular}{|l|l|}
\hline 53 & $\mathrm{X}$ \\
\hline
\end{tabular}

$\mathrm{X}$ X

$\mathrm{X} \quad \mathrm{X}$

$\mathrm{X}$

$\mathrm{X}$

\begin{tabular}{lll|l|l|l} 
& & & &
\end{tabular} 


\begin{tabular}{|c|c|c|c|c|c|c|c|c|c|c|c|c|c|c|c|c|c|c|c|}
\hline 54 & $\mathrm{X}$ & & & & $\mathrm{X}$ & & & & & & $\mathrm{X}$ & & $\mathrm{X}$ & $\mathrm{X}$ & & & & & \\
\hline 55 & $\mathrm{X}$ & & $\mathrm{X}$ & $\mathrm{X}$ & $\mathrm{X}$ & & & & & & $\mathrm{X}$ & $\mathrm{X}$ & & $X$ & & & & $\mathrm{X}$ & \\
\hline 56 & & & $\mathrm{X}$ & & & & & & & & & & & & & & & & $\mathrm{X}$ \\
\hline 57 & $\mathrm{X}$ & & & & $\mathrm{X}$ & & & & & & $\mathrm{X}$ & $\mathrm{X}$ & & $\mathrm{X}$ & & & & $\mathrm{X}$ & \\
\hline 58 & & & $\mathrm{X}$ & & & & & & & & & $\mathrm{X}$ & $\mathrm{X}$ & & & & & & \\
\hline 59 & $\mathrm{X}$ & & & & $\mathrm{X}$ & & & & & $\mathrm{X}$ & & & & $\mathrm{X}$ & & & & & \\
\hline 60 & & & & $\mathrm{X}$ & & & & & & & & $\mathrm{X}$ & $\mathrm{X}$ & $\mathrm{X}$ & & $\mathrm{X}$ & & & \\
\hline 61 & $\mathrm{X}$ & $\mathrm{X}$ & & $\mathrm{X}$ & $\mathrm{X}$ & & & $\mathrm{X}$ & $\mathrm{X}$ & $\mathrm{X}$ & $\mathrm{X}$ & $\mathrm{X}$ & $\mathrm{X}$ & $\mathrm{X}$ & $\mathrm{X}$ & & $\mathrm{X}$ & $\mathrm{X}$ & $\mathrm{X}$ \\
\hline 62 & $\mathrm{X}$ & & & $\mathrm{X}$ & $\mathrm{X}$ & & & & & & $\mathrm{X}$ & & & & & $\mathrm{X}$ & & & \\
\hline 63 & $\mathrm{X}$ & & & $\mathrm{X}$ & $\mathrm{X}$ & & & & & X & $\mathrm{X}$ & & $\mathrm{X}$ & $\mathrm{X}$ & $\mathrm{X}$ & & & & \\
\hline 64 & $X$ & & & $\mathrm{X}$ & $\mathrm{X}$ & & & & & & $\mathrm{X}$ & & & $\mathrm{X}$ & & $\mathrm{X}$ & & & \\
\hline 65 & $\mathrm{X}$ & & & $\mathrm{X}$ & $\mathrm{X}$ & & & & & $\mathrm{X}$ & $\mathrm{X}$ & & & $\mathrm{X}$ & & $\mathrm{X}$ & & $\mathrm{X}$ & \\
\hline 66 & $\mathrm{X}$ & & & $\mathrm{X}$ & $\mathrm{X}$ & & & & & & $\mathrm{X}$ & $\mathrm{X}$ & $\mathrm{X}$ & & $\mathrm{X}$ & & & $\mathrm{X}$ & $\mathrm{X}$ \\
\hline 67 & $\mathrm{X}$ & & & & & & & & & & $\mathrm{X}$ & & $\mathrm{X}$ & $\mathrm{X}$ & & & & & \\
\hline 68 & $\mathrm{X}$ & & $\mathrm{X}$ & & & & $X$ & & & $\mathrm{X}$ & $\mathrm{X}$ & & & & & & & & \\
\hline 69 & & & & & & & & & & $\mathrm{X}$ & & & & & & & & $\mathrm{X}$ & $\mathrm{X}$ \\
\hline 70 & & & & & & & & $\mathrm{X}$ & & $\mathrm{X}$ & & & & & & $\mathrm{X}$ & & & \\
\hline 71 & $\mathrm{X}$ & $\mathrm{X}$ & & $\mathrm{X}$ & $\mathrm{X}$ & & $\mathrm{X}$ & $X$ & $X$ & $\mathrm{X}$ & $\mathrm{X}$ & $\mathrm{X}$ & $\mathrm{X}$ & $\mathrm{X}$ & $\mathrm{X}$ & $\mathrm{X}$ & & $\mathrm{X}$ & X \\
\hline 72 & $\mathrm{X}$ & & & $\mathrm{X}$ & $\mathrm{X}$ & & $X$ & $X$ & $X$ & $\mathrm{X}$ & $\mathrm{X}$ & & & $\mathrm{X}$ & $\mathrm{X}$ & $\mathrm{X}$ & & $\mathrm{X}$ & \\
\hline 73 & & & & & & & & & & & & & & & & $\mathrm{X}$ & & & \\
\hline 74 & & & & $\mathrm{X}$ & & & & & & & & & & $\mathrm{X}$ & & & & & \\
\hline 75 & $\mathrm{X}$ & & & $\mathrm{X}$ & $\mathrm{X}$ & & & & & $\mathrm{X}$ & $\mathrm{X}$ & & & & & & & & \\
\hline 76 & & & & & & & & & & & & & & & & & & $\mathrm{X}$ & \\
\hline 77 & & & $\mathrm{X}$ & $\mathrm{X}$ & $\mathrm{X}$ & & $\mathrm{X}$ & & & X & $\mathrm{X}$ & & $\mathrm{X}$ & $\mathrm{X}$ & & & & $\mathrm{X}$ & \\
\hline 78 & $\mathrm{X}$ & & & $\mathrm{X}$ & $\mathrm{X}$ & & & & & $\mathrm{X}$ & $\mathrm{X}$ & $\mathrm{X}$ & $\mathrm{X}$ & $\mathrm{X}$ & & & & $\mathrm{X}$ & \\
\hline 79 & & & & & & & & & & & & & & & & & & $\mathrm{X}$ & \\
\hline 80 & $\mathrm{X}$ & & & $\mathrm{X}$ & $\mathrm{X}$ & & & & & $\mathrm{X}$ & $\mathrm{X}$ & & & $\mathrm{X}$ & & & & & \\
\hline 81 & $\mathrm{X}$ & $\mathrm{X}$ & & $\mathrm{X}$ & $\mathrm{X}$ & $\mathrm{X}$ & & & & $\mathrm{X}$ & & & $\mathrm{X}$ & & & & $\mathrm{X}$ & & \\
\hline 82 & & $\mathrm{X}$ & & & $\mathrm{X}$ & & & & & & & & & & & & & & \\
\hline 83 & & $\mathrm{X}$ & & & $\mathrm{X}$ & $\mathrm{X}$ & & & & & & & & & & & & & \\
\hline 84 & & $\mathrm{X}$ & & & $\mathrm{X}$ & & & & & & & & & & & & $\mathrm{X}$ & & \\
\hline 85 & & & & & & & & & & $\mathrm{X}$ & & & & & & & $\mathrm{X}$ & & \\
\hline 86 & & $\mathrm{X}$ & $\mathrm{X}$ & & & & & & & & & & & & $\mathrm{X}$ & & $\mathrm{X}$ & $\mathrm{X}$ & \\
\hline 87 & & & & $\mathrm{X}$ & & & & & & & & & & & & & & & \\
\hline 88 & & & & $\mathrm{X}$ & & & & $\mathrm{X}$ & $\mathrm{X}$ & $\mathrm{X}$ & & & & & $\mathrm{X}$ & & & & \\
\hline 89 & & & & & & $\mathrm{X}$ & & & & & & & & & & & & & \\
\hline 90 & & $\mathrm{X}$ & & & $\mathrm{X}$ & $\mathrm{X}$ & & & & & $\mathrm{X}$ & & & $X$ & & & $\mathrm{X}$ & & \\
\hline 91 & & & & & & $\mathrm{X}$ & & & & X & & & & & & & & $\mathrm{X}$ & \\
\hline 92 & & & & & & & & & & & & & & & & & & $\mathrm{X}$ & \\
\hline 93 & & & & & & & & & & & & & & & & & & $\mathrm{X}$ & \\
\hline 94 & & & $\mathrm{X}$ & & & & & & & & & & & & & & & $\mathrm{X}$ & \\
\hline 95 & & & & & & $\mathrm{X}$ & & & & & & & & & & & & & \\
\hline
\end{tabular}

\subsection{Assessment of Documents Utilized to Determine User Requirements in Residential Interior Design}

The documents provided in Table 1 and Table 2 and questions on these documents will be assessed in two different ways as qualitatively and quantitatively in order to determine how the documents which the students will benefit from while determining user requirements at the preliminary stage of the project within the purview of "Interior Architecture Design Studio" courses within the interior design undergraduate education will be.

\subsubsection{Assessment of Documents Utilized to Determine User Requirements in Residential Interior Design Quantitatively}

It can be seen that numerical distribution by resources shows differences as in Graphic 1 when questions in Table 1 and Table 2 are evaluated quantitatively. For Example;
Wentzel Design [17] and Rachel Blindau [19], T. Mcintyre Associates Residental Architectures [23], IMHS [14] and Murray Arnott Design [13] make assessments to determine user requirements as to residential interior design by basing on $6,21,28$ and 37 questions respectively. In other words, it has been determined that these documents which are utilized for the same purpose have a formation for obtaining data at different levels.

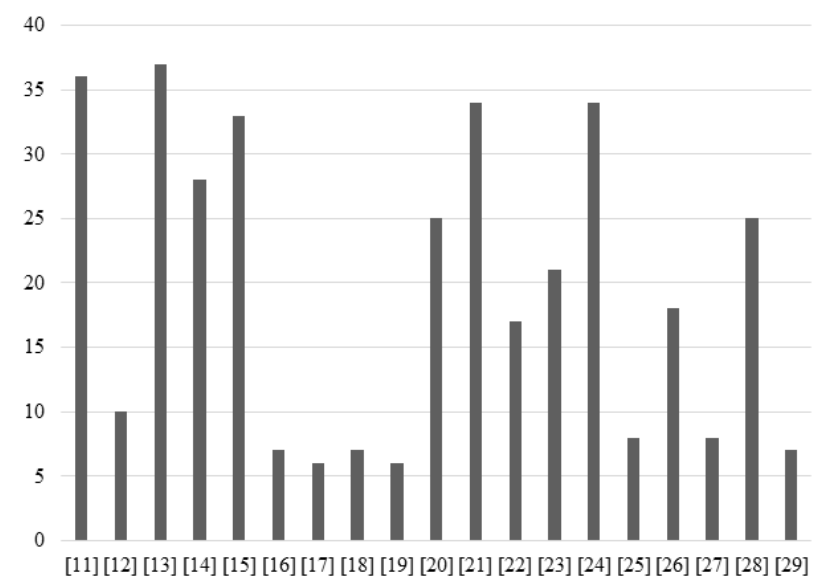

Graphic 1. Numerical distribution of Questions by resources

It can be seen that even the most frequently asked question which is "What style do you like and dislike?" was used in only16 of the 19 sources as seen in Graphic 2 when questions used to determine the user requirements in the residential interior design are evaluated in terms of frequency of use by sources. Similarly, presence of "What is the budget for your project?" question was determined in only 15 sources. In other words, it was understood that even the most important questions for determining user requirements which should be in all documents were not included in some documents.

\section{Are there types of window treatment you prefer?}

What kind of materials do you prefer?

What is your personal design goals for your home?

Household members (name, work,space,special needs,...

What is the scope of project?

What is the size/volume of home?

What are your

favorite/unfavorite color?

Which rooms will be included in the project?

What is the budget for your project?

What style do you like and dislike?
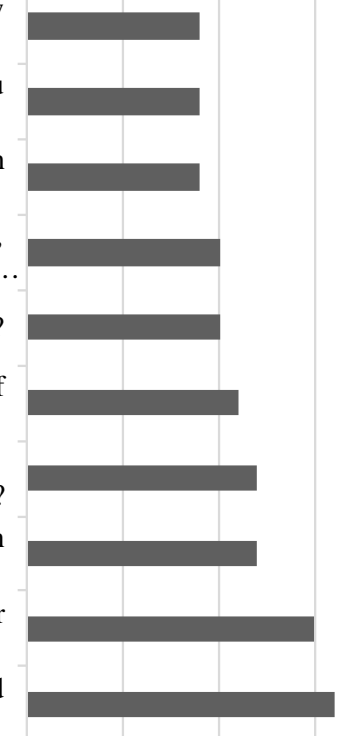

$\begin{array}{llll}0 & 5 & 10 & 15\end{array}$

Graphic 2. Frequency of use of most frequently asked questions by resources

3.1.2. Assessment of Documents Utilized to Determine User Requirements in Residential Interior Design Qualitatively 
In the qualitative assessment phase of the questions utilized for determining the user requirements in Table 1 , firstly a literature research was conducted to determine what the criteria to be based on should be when making this assessment. As a result of this research, it was observed that the following 21 different criteria should be considered $[8,30]$ :

1. The question should be focused on a single issue or topic.

2. The question should be brief.

3. The question should be interpreted the same way by all respondents.

4. The question should include all neccessary information.

5. The question should include response catagories clear and logical.

6. The question should use the respondent's core vocabulary.

7. The question should be a grammatically simple sentence if possible.

8. The question should not assume criteria that are not obvious.

9. The question should not be beyond the respondent's ability or experience.

10. The question should not use a specific example to represent a general case.

11. The question should not ask the user to recall specifics when only generalities will be remembered.

12. The question should not require the user to guess a generalization.

13. The question should not ask for details that cannot be related.

14. The question should not use words that overstate the condition.

15. The question should not use words that abbreviations, jardon or foreing phrases.

16. The question should not have ambiguous wording.

17. The question should not be "double-barreled."

18. The question should not lead the user to a particular answer.

19. The question should not have "loaded" wording or phrasing.

20. The question should not be too demanding and time consuming.

21. The question should not be biased.

When the questions to understand user requirements were evaluated on the basis of the 21 criteria mentioned hereinabove it was found that most of them made receipt of clear and correct answers dificult. For Example; the answer to the question of "What are your favorite / unfavorite colors?" to be given by the user will be probably light green, dark blue, orange and etc. However, the color tones which the user envisages by the concepts of light green or dark blue has very low probability to correspond with the color tones which the designer envisages. Any mistake to be made here may cause very adverse outcomes in terms of user satisfaction [3].

Similarly when the questions regarding the determination of style were evaluated, it was found that there are two questions which are "What style do you like and dislike?" and "What is the existing style of your home?” in order to understand it. Additionally, in some sources [11,14,21,24] styles were tried to be described through a variety of visuals. However, these visuals do not have the quality to convey full and sufficient data related to these styles to the user. In other words, language unity between designers and users cannot be provided in the existing documents.

Furthermore, it was seen that none of these questions are intended for "cultural Implications". However, many behaviors including the way of eating recreation and fun vary considerably from culture to culture regarding the usage of houses [3].

There are only two questions to recognize the user's physical characteristics which are "Household members (name, work, space, special needs, birthday)" and "Special considerations (disabled, elderly or children)?”. However, these questions are not intended to understand the anthropometric measurements of users such as height, weight and etc. which are very important in interior design. For example two users with the same age and gender but with different heights such as $187 \mathrm{~cm}$. and $155 \mathrm{~cm}$ can reach completely different heights. This in particular will affect the design of storage spaces significantly.

It is not possible for the existing documents and questions in these documents to identify user requirements adequately and correctly due to all these determined deficiencies. Therefore, suggestions will be made for the elimination of these deficiencies in the next phase of the study.

\section{Suggestions for Creation of Documents to Ensure Identification of User Requirements in Residential Interior Design Correctly and at an Adequate Level}

The use of all of the 95 different questions listed in Table is suggested in creation of documents to ensure identification of user requirements in residential interior design correctly and at an adequate level.

Identification of questions for learning anthropometric measurements of users is also suggested in the newly created documents. These questions should be identified by taking into consideration actions to be performed in the space and action groups and in an answerable way. In other words, which anthropometric measures should be taken for which actions should be included in the documents.

It is suggested to create the new questions in a way to ensure the receipt of clear and accurate answers. As in the color example provided hereinabove, the user should be enabled to choose from a color chart instead of saying the name of color and tone.

It is suggested to create questions identifying the cultural characteristic of users in the new documents. These questions should be created basing on actions that differ from culture to culture in terms of residential interior design.

\section{Results}

It will be possible to create the documents to be utilized to determine the user requirements in residential interior 
design correctly and completely in line with the suggestions to be made within the scope of the study. The use of these documents to be created anew will improve the students' performance success significantly within the purview of "Interior Architecture Design Studio" courses within the interior design undergraduate education.

\section{References}

[1] Yazıcıoğlu, D.A. (2014). An Analytical Approach on Improvement of Kitchen Design Performance In Terms of PsychoSocial User Requirements In Turkey, Advances in Social Sciences Research Journal, Vol. 6, No. 1, 2014, pp. 179-186.

[2] Arslan, S. and Kanoğlu, A. (2010). Başarım Tabanlı Yapım: Anahtar Kavramlar, Olanaklar, Bariyerler ve Bir Model, 1. Proje ve Yapım Yönetimi Kongresi, 29 Eylül - 1 Ekim 2010 ODTÜ Kültür ve Kongre Merkezi, Ankara.

[3] Karaaslan, T. and Yazicioglu, D.A. (2015). Enhancement of The Designer Performance In Office Interior Design, Advances in Social Sciences Research Journal, Vol.2, No.1, pp. 139-146.,

[4] Addi, G. and Lytle, J. (2000). Interior Design, Excerpt from The Architect's Handbook of Professional Practice, Associate AIA.

[5] Ching, F.D.K. (2004). İç Mekan Tasarımı-Resimli, Yapı Yayın, İstanbul.

[6] Arcan, E.F. and Evci, F. (1992). Mimari Tasarıma Yaklaşım 1Bina Bilgisi Çalışmaları, İki k Yayınevi, İstanbul.

[7] Stephenson, H. and Stephenson, L. (1960). Interior Design, Studio Books, London.

[8] e-bookspdf. (2014). Designing Data Collection Forms, [Online]. Available: http://www.e-bookspdf.org/view/aHR0cDovL3Z1bG1 zLnZ1LmVkdS5way9Db3Vyc2VzL01HVDYxOS9Eb3dubG9hZ HMvRGVzaWduaW5nJTIwRGF0YSUyMENvbGxlY3Rpb24lMj BGb3Jtcy1RdWVzdGlvbm5haXJlcy5wZGY=/VGhlIEZ1bmN0a W9ucyBPZiBBIFF1ZXN0aW9ubmFpcmUgLSBMZWFybmluZy BNYW5hZ2VtZW50. [Accessed Dec.3, 2014].

[9] Burns, A.C. and Bush, R.F. (2013). Marketing Research: Online Research Applications, Pearson Education, Inc. Published by Prentice Hall, Inc.

[10] CTA. (2014). Design Build Process, [Online]. Available: http://www.ctabuilds.com/wp-content/uploads/2014/01/CTADesign-Build-Process.pdf. [Accessed Dec.5, 2014].

[11] Studio of Interior Design. (2014). New Client Questionnaire, [Online]. Available:

http://www.studioofinteriordesign.com/NewClientQuestionnaire.p df. [Accessed Dec.10, 2014].

[12] Studio 10 Interior Design.(2014). Client Questionnaire, [Online]. Available:

http://studio10interiordesign.com/wp-content/uploads/clientquestionnaire.pdf. [Accessed Dec.10, 2014].

[13] Murray Arnott Design.(2014). Client Questionnaire, [Online]. Available: http://www.designma.com/pdf/client_questionnaire.pdf. [Accessed Dec.10, 2014].

[14] IMHS.(2014). Interior Decoration Questionnary, [Online]. Available:

http://impressmehomestaging.com/UserFiles/file/IMHS\%20Interio r\%20Decorating\%20Questionnaire.pdf. [Accessed Dec.10, 2014].

[15] MMID. (2014). Client Questionnaire Working [Online]. Available: http://michelinadesign.com/mmidcorp/wpcontent/uploads/2014/05/client-questionnaire_working.pdf. [Accessed Dec.10, 2014].
[16] Design Success University. (2014). Client Interview Questionnaire, [Online]. Available:

https://www.designsuccessu. com/wp-content/uploads/ClientInterview-Questionnaire.pdf. [Accessed Dec.10, 2014].

[17] Wentzel Design.(2014). Client Questionnaire, [Online]. Available: http://www.wentzeldesign.org/upload/Client\%20Questionnaire.pd f. [Accessed Dec.10, 2014].

[18] Redmond Aldrich Design. (2014). Design Kit- Client Questionnaire, [Online]. Available: http://www.redmondaldrich. com/designkit/DesignKit_Client_Pack.pdf. [Accessed Dec.10, 2014].

[19] Rachel Blindauer.(2014). Design Client Questionnare, [Online]. Available:

http://www.rachelblindauer.com/E-DesignClientQuestionnare.pdf. [Accessed Dec.10,2014].

[20] e-bookspdf.(2014). Divine Elements of Design New Client Questionnaire, [Online]. Available:

http://www.e-

bookspdf.org/view/aHR0cDovL3d3dy5kaXZpbmVlbGVtZW50c2 9mZGVzaWduLm5ldC9hcHAvZG93bmxvYWQvMTA0OTg1M C9ERU9EX05ld19DbGllbnRfUXVlc3Rpb25uYWlyZS5wZGY=/ TmV3IENsaWVudCBRdWVzdGlvbm5haXJlIC0gRGl2aW5lIEV sZW1lbnRzIE9mIERlc2lnbiAtIEhvbWU=. [Accessed Dec.10, 2014].

[21] Sher Colquitt Interiors.(2014). New Client Questionnare, [Online]. Available:

http://shercolquittinteriors.com/docs/SC_NewClientQuestionnaire _F.pdf. [Accessed Dec.10, 2014].

[22] Mountain Creek Home. (2014). Client Design Questionnaire, [Online]. Available:

http://mountaincreekhomesaz.com/wpcontent/uploads/2013/11/Client-Design-Questionnaire-2.pdf. [Accessed Dec.10, 2014].

[23] T. Mcintyre Associates Residental Architectures.(2014). New Client Questionnare, [Online]. Available: http://tmcintyre.com/Questionnaire.pdf. [Accessed Dec.10, 2014].

[24] FPI.(2014). New Client Questionnare, [Online]. Available: http://www.fpiplus.com/wp-content/uploads/2012/03/NEWCLIENT-QUESTIONNAIRE.pdf. [Accessed Dec.10, 2014].

[25] Amber Interior Design.(2014). e-Decoration Questionnaire [Online]. Available:

http://amberinteriordesign.com/e-decor/questionnaire/. [Accessed Dec.10, 2014].

[26] Great Sample Resume.(2014). Interior Design Questionnaire, [Online]. Available: http://www.greatsampleresume.com/Questionnaires/InteriorDesign-Questionnaire/. [Accessed Dec.10, 2014].

[27] Pulp Design Studios. (2014). Client Questionnare, [Online]. Available:

http://pulpdesignstudios.com/client-questionnaire. [Accessed Dec.10, 2014].

[28] BH Interiors Design .(2014). Informational Questionnaire for interior design, [Online]. Available: http://joyceisnothere.typepad.com/design/2009/10/informationalquestionnaire-for-interior-design.html. [Accessed Dec.10, 2014].

[29] Susan E. Brown Interior Design.(2014). Client Questionnaire, [Online]. Available: http://susanebrown.com/?page_id=422. [Accessed Dec.10, 2014].

[30] Taylor-Powell, E. (1998). Questionnaire Design: Asking Questons With A Purpose, University of Wisconsin-Extension,Mary G.Marchall Publications. 